\title{
A Survey on the Determinants of Entrepreneurial Training Effectiveness among Micro Finance Institutions of Malaysia
}

\section{Syed Hussain Haider}

Project Director, Akhuwat Institute of Social Enterprise and Management Adjourned faculty LUMS, Pakistan; syedhussainhaider@gmail.com

\section{Muzaffar Asad}

PhD Scholar at College of Business (COB), University Utara Malaysia (UUM), Malaysia muzaffar.asad@ucp.edu.pk

Atif Aziz

School of Business Management (SBM), College of Business (COB), University Utara Malaysia (UUM), Malaysia

\author{
Doi:10.5901/mjss.2015.v6n6s4p396
}

\section{Abstract}

The importance of the training is increasing day by day not only in corporate sector but also in entrepreneurial sector. This study aims to evaluate the influencing factors of entrepreneurial training effectiveness of Malaysian microfinance institutions (hereinafter MFIs). This study use survey research design and involve four listed MFIs of Malaysia that are selected on the base of engagement in entrepreneurship training during last five years. Questionnaires are used to collect data from selected respondents by using stratified random sampling. Results of the study reveal that deteriorating rate of small and micro enterprises is increasing rapidly due to inappropriate training and non-allocation of sufficient funds. Findings confirm the relationship between entrepreneurial training effectiveness and training need analysis. Training contents also found a critical and important factor for training effectiveness. Results also show that there is a need to undertake a comprehensive analysis by MFIs on individual entrepreneurs and the job tasks in order to estimate their training needs. In this way, the need of clients for appropriate and relevant training can be addressed in a better way.

Keywords: Entrepreneurial training, Malaysian microfinance institutions, training effectiveness.

\section{Introduction}

Small and micro financial enterprises of developing countries are facing serious problems related to low survival rate or high failure rate of newly setup enterprises. The findings of past studies reveal the main reasons of high failure rate of small enterprises in the world that include improper funding, lack of entrepreneurial skills, poor management and low level of technical knowledge (Elmuti, Khoury, \& Omran, 2012; Jusoh, Ziyae, Asimiran, \& Kadir, 2011; Rodrigues, Dinis, do Paço, Ferreira, \& Raposo, 2012). However, the clients of MFIs (i.e. micro entrepreneurs) have availability of entrepreneurial trainings and access to adequate funding. Therefore, the use of integrated development models are much appreciated by MFIs due to this assertion that lack of management skills and limited access to credit facilities are the main problems of micro entrepreneurs (Williams, 2015). Therefore, MFIs are focusing on both appropriate training needs and provision of adequate finances in order to enable them to take good business start and expand their business activities in their locality leading towards the growth of sustainable economy and micro enterprises (Ehrlich, De Noble, Jung, \& Pearson, 2000; Farsi, Arabiun, \& Moradi, 2012; Lashgarara, Roshani, \& Najafabadi, 2011; Teoh \& Chong, 2008).

Notwithstanding to these facts, the survival rate of micro enterprises is very low in the world and, in result, their default ratio point towards the unsuccessfulness of entrepreneur business (Echtner, 1995). Management incompetency and the lack of entrepreneurial experience, knowledge, and skills are the most common reasons of failure (Yamakawa \& Cardon, 2015). There is a big misconception among small enterprises that the availability of finance is the only key success factor for any business which often proves fail after few years of businesses (Williams, 2015). Studies has shown that allocation of funds to small enterprises without passing them appropriate skills and knowledge and without preparing entrepreneurs how to effectively and efficiently use those funds would leads towards insolvency (Elmuti et al., 2012). 
Therefore, it can be concluded that for the survival and success of small enterprises trained micro entrepreneurs are the critical and essential factor of their businesses.

Global statistics reveal the fact that approximately one third of small enterprises discontinue their business operations within one year; almost half of the businesses become fail within two years; and approximately $2 / 3$ of total businesses close their operations within five years (Echtner, 1995). On the contrary, when training is provided to entrepreneurs, it enhances their managerial and administrative skills which ultimately improve their performance reflected through high survival rates or low failure rates (Ogundele, Akingbade, \& Akinlabi, 2012; Omar, Nazri, \& Wel, 2014; Sharma, 2014). Beardwell, Holden, and Claydon (2004) suggest, however, that there is great variability in training types which, consequently, demands careful consideration and inclusion of those training factors that enhance the effectiveness of entrepreneurial training program. This conception encouraged the authors to undertake this study to evaluate factors that affect the training effectiveness among entrepreneurs provided by MFIs of Malaysia. The focus of this study is on the determinants of the training needs analysis and their effectiveness among small enterprises in Malaysia. This study aims to achieve following objectives:

$>$ To examine the impact of training needs analysis undertaken by Malaysian MFls on the effectiveness of entrepreneurial training.

$>$ To determine the effect of training contents developed Malaysian MFIs on the effectiveness of entrepreneurial training.

\section{An Overview of Malaysian MFls}

According to Census of Establishments and Enterprises of 2005, $80 \%$ of small and medium enterprises (SMEs) of Malaysia are constituted by micro enterprises. Most importantly, to ensure balance and equitable economic growth, the development of micro enterprises is very much critical for a society. The development and growth of microfinance industry in Malaysia is one of the important objectives of Bank Negara Malaysia to ensure that all communities, sectors and regions have adequate access to their relevant financial products and services. In order to develop sustainable microfinance industry, National SME Development Council (NSDC) approved microfinance framework in August 2006, suggested by Bank Negara Malaysia, which comprised of credit cooperatives, banking institutions and development financial institutions (DFIs). Other listed banks are working as additional sources of finance through their nationwide branch network to provide easy access of funding. According to annual report 2007 of Bank Negara Malaysia, there are currently nine financial institutions that have introduced their microfinance products in the market. The composition of these institutions includes six banking institutions and three DFls. Different business models are adopted by these institutions in order to meet diverse financial requirements of small enterprises in the country.

Ministry of Entrepreneur and Cooperative Development (MECD) released its statistical report which reveals the number of individual entrepreneurs increased by $75.79 \%$ over the period of 1995 to 2000 . The Census of Establishment and Enterprises (CEE) was conducted by Department of Statistics Malaysia in 2005, which disclose astonishing facts that $78.7 \%$ of total SMEs $(548,267)$ established in Malaysia are contributed by micro enterprises in which almost $16 \%$ are women owned enterprises (Teoh \& Chong, 2008). In all three main sectors (i.e. manufacturing, services and agriculture) of Malaysia, micro enterprises are involved and working actively.

\section{Literature Review}

To acquire proficiency and getting expert of particular skills is known as training (Armstrong, 2010). Through training, the specified behavior, skills and knowledge are transferred to trainee relevant to his assigned task (Balkin, 2015). After getting training, small entrepreneurs equipped with practical skills and knowledge which is related to their specific competencies. A large number of studies address the importance of the analysis of training need among entrepreneurs and their impact on SMEs. Jusoh et al. (2011), for example, conducted interviews from thirty entrepreneurs inside Malaysia in order to investigate the competencies required for successful business. Their study confirms the notion of entrepreneurship education which generates a significant difference in entrepreneurs' performance, while entrepreneurs are willing for further education and training in specific business issues. Similarly, the study of Williams (2015) analyzed the effect of entrepreneurial training, evolution and education outside the firm on business failure rate among 43 developing economies. By developing a conceptual model their results show that environment evolution has significant influence on business discontinuation.

In tourism industry, Echtner (1995) used three-pronged approach to evaluate entrepreneurial development and training. They found that the primary goal of tourism industry in developing countries is not only to improve tourism sector 
but they also focus on training and development of entrepreneurs to assure successful running of small tourism enterprises. Likewise, Omar et al. (2014) conducted interviews from low-income women to explore the challenges and problems that they face related to entrepreneurial training in micro enterprises among service type organizations. They found that during work they also demand child care facilities to cope between work and family. They suggest some relevant and important contents about training modules that should be included in training programs such as IT training, use of advance equipments etc. In order to grow micro business in India, Sharma (2014) conducted his study to examine entrepreneurial training among SMEs. He found that key factor in SEMs failure in India lies in the mismanaged entrepreneurships. He argued that entrepreneurs should be equipped with managerial skills which can be only achieved though training programs.

The intensity of entrepreneurial education and training programs in reducing poverty in Nigeria is investigated by Ogundele et al. (2012). The sample of 250 entrepreneurs confirmed that entrepreneurial education and training have a great influence on social welfare services and youth empowerment. Likewise, the analysis of training methods and training course contents in South Africa was undertaken by Ladzani and Van Vuuren (2002) and found the need for training along with some significant deficiencies and flaws in existing entrepreneurial training program. Ehrlich et al. (2000) examined the influence of entrepreneurship trainings on entrepreneurial self-efficacy. Their results indicate that entrepreneurial training significantly and positively impacted participants' perceptions of their abilities to pursue and grow new ventures.

Luca and Cazan (2011) explore the relationship between the entrepreneurial traits and the involvement in the entrepreneurial and development competences through training sessions offered by the university. Statistically significant relationship was found between entrepreneurial potential and other variables which include creativity, internal locus of control, resources organizations and entrepreneurial skills. The study of Rusinà, Dalla Pellegrina, Di Maio, and Landoni (2015) focuses on entrepreneurial training plan and integrating a money management in a non-profit MFIs in Kolkata, India and measured the marginal impact of training on the beneficiaries through a randomized control trial. They found significant and positive effects on financial management skills and institutional outcomes of the clients. Roshan, Seifi, Abdollahi, Nokani, and Banijamali (2015) investigate the relationship between student's entrepreneurship spirit and teachers entrepreneurial training. By using multi stage stratified sampling method; total 500 respondents confirmed the positive and significant relationship between entrepreneurial training and students' entrepreneurship spirit. However, they did not found any correlation between student's entrepreneurship spirit and objectives of Entrepreneurial training.

\section{Theoretical Framework}

This study based on 'adult learning theory' in which adults are classified by level of experiences they posses, they are curious to gain new knowledge relevant to their experience and their instant needs. The focus of the theory is on the analysis of training needs and its contents that must be considered in order to make effective entrepreneurial training program. Training is considered as systematic process in which every element, such as environment, materials, learner and trainer is critically effective which ultimately improve business performance and, in turn, reduce mortality rates of microenterprises (Beardwell et al., 2004; Hui, 2012; Ladzani \& Van Vuuren, 2002). In this scenario, it is essential that training provider institutes (such as microfinance institutions) apply adult learning theory in order to make their entrepreneurial training program more effective and result oriented.

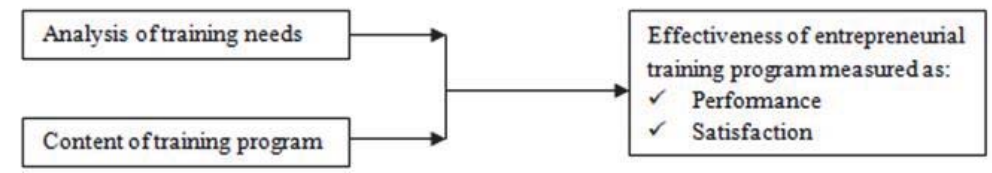

Figure 4.1: Factors affecting effectiveness of entrepreneurial training program

\section{Methodology}

This is a descriptive study uses survey research design and collect data through semi-structured questionnaire. There are ten MFIs listed in Bank Negara Malaysia but selected four that are vigorously involved in entrepreneurial training from last 5 years named AmBank Berhad, Agrobank, RHB Bank Berhad and SME bank. The elements of the targeted population are 225 comprised of administrative workers, trainees and trainers working of these MFIs. Sample size of 80 respondents 
was proportionately drawn from targeted population of four MFIs. They decimals answers were rounded off due to adjustment for single person. Seven administrative workers, nine trainers and sixty four trainees totaling eighty respondents were selected by stratified random sampling. Authors personally met and collected data from 80 respondents through questionnaire. The summary of total population elements and sample selection are given in Figure 5.1 and Figure 5.2. After data collection, raw data was passed through the process of checking consistency, uniformity of entry, accuracy and completion. Descriptive statistical methods were used to present data in more understandable form such as bar \& pie charts, frequency distribution and percentages. The check the difference of opinion between respondents about determinants of entrepreneurial training effectiveness, we use Chi-square test.

Table 5.1: Summary of population elements

\begin{tabular}{|l|c|c|c|c|}
\hline MFls & Administrative workers & Trainers & Trainees & Total no. of respondents \\
\hline AmBank Berhad, & 3 & 6 & 33 & 42 \\
\hline Agrobank, & 5 & 5 & 43 & 53 \\
\hline RHB Bank Berhad & 6 & 8 & 62 & 76 \\
\hline SME bank & 5 & 7 & 42 & 54 \\
\hline Total & 19 & 26 & 180 & $\mathbf{2 2 5}$ \\
\hline
\end{tabular}

Table 5.2: Summary of sample selection

\begin{tabular}{|l|c|c|c|}
\hline Population Elements & Total number of people & Proportion of total sample & Size of a sample \\
\hline Administrative Workers & 19 & 0.0844 & 7 \\
\hline Trainers & 26 & 0.1155 & 9 \\
\hline Trainees & 180 & 0.8000 & 64 \\
\hline Total & 225 & 1.0000 & 80 \\
\hline
\end{tabular}

\section{Results and Discussion}

\subsection{Survey Response Rate}

The analysis of the collected data was performed through inferential and descriptive statistics in accordance with the relevance of study. Almost all respondents completed and returned their questionnaires at given time with some exceptions that were contacted again through telephone or email to ensure response rate at $100 \%$. The response rate for each category of the respondents is illustrated in Table 6.1.

Table 6.1.1: Response rate for each category of sample

\begin{tabular}{|l|c|c|c|c|}
\hline Population Elements & Size of Population & Sample Size & Successful completion & Response rate \\
\hline Administrative Workers & 19 & 7 & 7 & $100 \%$ \\
\hline Trainers & 26 & 9 & 9 & $100 \%$ \\
\hline Trainees & 180 & 64 & 64 & $100 \%$ \\
\hline Total & 225 & 80 & 80 & $100 \%$ \\
\hline
\end{tabular}

\subsection{Demographic Characteristics of Administrative Workers and Trainers}

Both males and females took participate in a survey. Out of total sample, 12 respondents were males (75\%) and 4 were females (25\%). Respondents fall in different age intervals. Only 3 respondents (approximately 19\%) were between the ages of 20 and 30, while half of the respondents (50\%) fall under the ages of 31 and 40 . And finally, 5 respondents (approximately 31\%) are above the age forty. Education level of the respondents also varies from low level to high level of education. Maximum number of respondents, i.e. 9 (approximately 56\%), hold masters degree, only 4 respondents (25\%) having bachelor/degree and, finally, 3 respondent (approximately 19\%) are having certificates or diplomas. Respondents were also asked about their professional experience based on number of years spend in different organizations. 4 respondents (25\%) have less than two year experience whereas 7 respondents (approximately 44\%) and 5 respondents (approximately 31\%) have professional experience between 2-5 years and 5-10 years respectively. None of the respondents have more than ten year experience. 


\subsection{Factors Affecting Effectiveness of Entrepreneurial Training Program}

Now we come towards the main objective of our study i.e. to investigate the factors that influence the effectiveness of entrepreneurial training program in MFIs of Malaysia. In this regard, we determine the influence of training need analysis undertaken by MFIs of Malaysia on the effectiveness of entrepreneurial training. Respondents were asked whether or not they ever conduct analysis of training needs. 13 respondents (approximately 81\%) give favorable reply that training need analysis was being conducted. It can be concluded that Malaysian MFIs are considering and focusing on training need analysis. It means that MFIs now should focus on determining skills, attitudes and knowledge. Armstrong (2010) suggests that by figuring out training need analysis, entrepreneurial training programs can make more effective through collecting comprehensive information about enterprise, jobs and individuals to determine training needs. Moreover, during training need analysis, respondents also provide their opinions about other dimensions of training need, i.e. task analysis, individual entrepreneur analysis, and enterprise analysis that are demonstrated in Table 6.3.1.

Table 6.3.1: Response rates of all dimensions of training need analysis

\begin{tabular}{|l|c|c|c|c|c|c|}
\hline & \multicolumn{2}{|c|}{ Task Analysis } & \multicolumn{2}{c|}{ Individual Entre. Analysis } & \multicolumn{2}{c|}{ Enterprise Analysis } \\
\hline Scale Responses & Frequency & Percentage & Frequency & Percentage & Frequency & Percentage \\
\hline Never & 0 & 0 & 0 & 0 & 2 & 12.5 \\
\hline Rarely & 4 & 25 & 2 & 12.5 & 2 & 12.5 \\
\hline Often & 6 & 37.5 & 3 & 18.75 & 4 & 25 \\
\hline Very often & 6 & 37.5 & 5 & 31.25 & 6 & 37.5 \\
\hline Almost always & 0 & 0 & 6 & 37.5 & 2 & 12.5 \\
\hline TOTAL & 16 & 100 & 16 & 100 & 16 & 100 \\
\hline
\end{tabular}

Information given in above table reveals many facts. The deep observation of the table indicates that task analysis is carried out (very) often inside MFIs of Malaysia as 75\% responses confirmed it. However, none of the respondents indicate regularity of this analysis. Secondly, responses about individual entrepreneur analysis specify that this analysis is carried out frequently inside MFIs. Finally, mixed responses were received about enterprise analysis as some says that this analysis is undertaken by MFIs very often and some says never/rarely. Therefore, the results of enterprise analysis are ambiguous which highlight the draw attention of the MFIs' management that they should concentrate and give attention to the need of enterprise analysis in their MFIs. However, results of rest of the analysis are adequately satisfactory.

Another important objective of this study is to determine the role and significance of training contents in making entrepreneurial training program effective. For this purpose, we also asked the respondents to provide us their opinions (through questionnaire) regarding impact of training contents on the effectiveness of entrepreneurial training in MFIs of Malaysia. The findings are summarized in following table.

Table 6.3.2: Response regarding impact of training contents on the effectiveness of entrepreneurial training program

\begin{tabular}{|l|c|c|}
\hline Scale Responses & Frequency & Percentage \\
\hline Strongly agree & 4 & 25 \\
\hline Agree & 6 & 37.5 \\
\hline Neutral & 4 & 25 \\
\hline Disagree & 2 & 12.5 \\
\hline Strongly disagree & 0 & 0 \\
\hline TOTAL & 16 & 100 \\
\hline
\end{tabular}

Above table shows that most of the respondents, i.e. 10 (62.5\%), are agreed and deemed that in improving effectiveness of entrepreneurial training programs, contents of the training play their significant role. Only two respondents (12.5\%) are against this notion. It should be noted that the training contents address the subject matter and issues about training program that should be take into consideration while conducting training before making decision about training techniques or strategies (Ladzani \& Van Vuuren, 2002). Most importantly, the training contents must be designed by keeping in view training objectives (Ogundele et al., 2012). 2 respondents out of 9 have no idea or understanding about the importance of training contents in respect of training program. 


\subsection{Demographic Characteristics of Trainees}

The demographic profile of the respondents that were trainees includes gender, age, their level of education etc. Out of 64 trainees, there were 20 (approximately 31\%) males and 44 (approximately 69\%) females. This ratio also in consistent with the Malaysian population feature where females are dominant, therefore several SMEs are owned and run by females. All respondents lie in different age brackets. Maximum respondents fall under 15-25 and 26-35 age brackets with 18 (approximately 28\%) and 27 (approximately 42\%) respectively. Whereas, 7 (approximately 11\%), 9 (approximately 14\%) and 3 (approximately 5\%) respondents fall under 0-14, 36-45 and 46-60 age brackets respectively. As for as education level of the respondents is concerned, 33 (approximately 52\%) respondents having O-level or foundation qualification while 11 and 15 respondents have diploma/certificate holders and bachelor/degree holders respectively. This also constitute a large part of total population with $41 \%$ approximately. Finally, only 2 (approximately $3 \%$ ) respondents were masters and 3 (approximately 4\%) respondents having no qualification. Finally, respondents are also asked about their level of experience in their field. A large number of respondents, i.e. 27 (approximately 42\%), having experience from 6-10 years whereas significant number of respondents, i.e. 24 (approximately 37.5\%) having experience from 3 to 5 years. Only 13 (approximately 20.5\%) respondents have more than ten year experience.

\subsection{Factors Affecting Effectiveness of Entrepreneurial Training Program}

The factors were also investigated from trainees that influence the effectiveness of entrepreneurial training program in MFIs of Malaysia. In this regard, we determine the influence of training need analysis undertaken by MFIs of Malaysia on the effectiveness of entrepreneurial training. For this purpose, data is initially analyzed by using chi-squared test for independence of the variables after collected from questionnaires. This will provide us information about the significant difference between observed frequencies of responses (collected from respondent) and three main elements of training needs analysis, i.e. task analysis, individual entrepreneur analysis, and enterprise analysis.

Table 6.5.1: Response rates of all dimensions of training need analysis

\begin{tabular}{|l|c|c|c|c|c|c|}
\hline & \multicolumn{2}{|c|}{ Task Analysis } & \multicolumn{2}{c|}{ Individual Entre. Analysis } & \multicolumn{2}{c|}{ Enterprise Analysis } \\
\hline Scale Responses & Frequency & Percentage & Frequency & Percentage & Frequency & Percentage \\
\hline Extremely Satisfied & 25 & 39 & 36 & 56.25 & 19 & 29.7 \\
\hline Satisfied & 21 & 33 & 11 & 17.18 & 15 & 23.4 \\
\hline Neutral & 5 & 8 & 4 & 6.25 & 12 & 18.7 \\
\hline Dissatisfied & 7 & 11 & 8 & 12.5 & 11 & 17.1 \\
\hline Extremely Dissatisfied & 6 & 9 & 5 & 7.82 & 7 & 11.1 \\
\hline TOTAL & 64 & 100 & 64 & 100 & 64 & 100 \\
\hline
\end{tabular}

Above table shows that responses of the respondents about said dimensions of training need analysis are divergent. Overall, 72\% respondents are satisfied that MFIs undertake analysis of the tasks for training purpose. However, only 13 (20\%) respondents show their dissatisfaction. As for as the analysis of individual entrepreneur is concerned, $73.43 \%$ respondents have perception that organization is serious and consider individual entrepreneurs in making effective training programs. Only fewer respondents are dissatisfied. Finally, the responses about enterprise analysis are almost evenly distributed on measurement scale. Approximately, $53 \%$ people rate MFIs concern about enterprise analysis while formulating their training program. However, significant percentage of neutral respondents, i.e. $18.7 \%$, is highly considerable which signifies that these respondents are not assuring about this element of training effectiveness.

Following table provides summary of test statistics of all aspects of entrepreneurial training effectiveness. The values in task analysis column show that Chi-square with degree of freedom 4 and $5 \%$ significance level is 0.056 which indicates that $p>0.05$. These results clearly indicate the relationship between entrepreneurial training effectiveness and task analysis. This implies that for effective entrepreneurial training program a comprehensive analysis should be conducted by gathering sufficient information about the task in order to determine training needs. Similarly, values in next column exhibit almost same results which confirm the relationship between entrepreneurial training effectiveness and individual entrepreneur analysis. Finally, the last column carry test statistics values of enterprise analysis. At $95 \%$ confidence interval, results verify the relation between entrepreneurial training effectiveness and enterprise analysis and signify that MFIs of Malaysian should conduct analysis of the enterprise before formulating any training program. 
Table 6.5.2: Combined Test Statistics

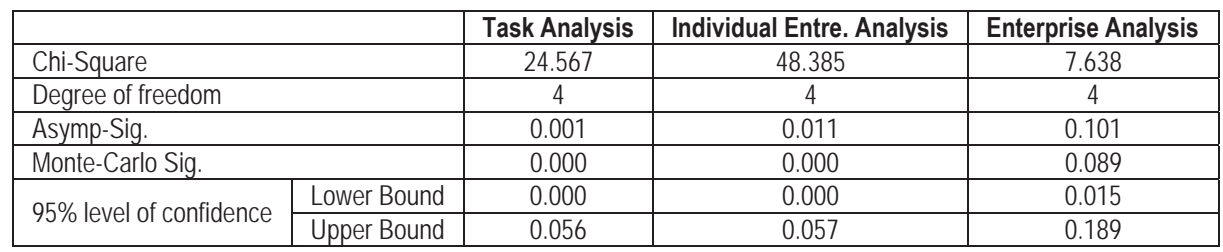

\subsection{Role of Training Contents in Entrepreneurial Training Effectiveness}

As discussed earlier, one of the aims of this study is to investigate how much training contents have influence over the effectiveness of entrepreneurial training of MFIs of Malaysia. To achieve this aim, trainees are also asked to give their opinion about it. The response frequency and percentage are given in table below.

Table 6.6.1: Response regarding impact of training contents on the effectiveness of entrepreneurial training program

\begin{tabular}{|l|c|c|}
\hline Scale Responses & Frequency & Percentage \\
\hline Strongly agree & 18 & 28.13 \\
\hline Agree & 24 & 37.5 \\
\hline Neutral & 11 & 17.19 \\
\hline Disagree & 6 & 9.37 \\
\hline Strongly disagree & 5 & 7.81 \\
\hline TOTAL & 64 & 100 \\
\hline
\end{tabular}

Above table shows survey responses about training contents obtained from trainees. 42 respondents (approximately $65 \%$ ) out of 64 agree that training contents play their critical role in effectiveness of training program. These results suggest to MFIs of Malaysia to keenly observe and much focus on training contents during designing training programs.

\section{Conclusion, Limitations and Future Research Avenues}

This study aims to evaluate important factors that affect entrepreneurial training programs in MFIs of Malaysia. This research is initiated based on the fact that though MFIs are providing finance to small entrepreneur businesses, but on the other hand, survival ratio of small entrepreneur businesses are getting low and their success rate is getting down in especially Asian countries like Malaysia. This fact calls for the research to investigate training need analysis among MFIs. Study findings indicate that there is a relationship between entrepreneurial training effectiveness and training need analysis. Analysis of training elements, i.e. task analysis, individual entrepreneur analysis and enterprise analysis, also high light the importance of separate analysis of task, individual entrepreneur and enterprise which should be undertaken by MFIs of Malaysia before design any training program. Most of the respondents are agree on this notion that training contents play key role in training effectiveness and should be designed by keeping in view the entrepreneur education, skills and experience level in order to make training relevant and effective.

There are several limitations which open the venues for future research. The total number of MFIs is only four and total respondents are 64. Same research can be conducted on large number of MFIs with large number of sample. Secondly, future research can also be undertaken by authors in different Asian countries like Thailand and Indonesia. Entrepreneur training need analysis only limited to MFIs of Malaysia, whereas other sectors of the economy can also be included in research. Finally, other tools can be employed by future researchers to make results more robust and reliable.

\section{References}

Armstrong, M. (2010). Armstrong's Essential Human Resource Management Practice: A Guide to People Management: Kogan Page.

Balkin, S. (2015). Self-Employment Training Programs for the Poor. Journal of Small Business Strategy, 1(2), 47-57.

Beardwell, I., Holden, L., \& Claydon, T. (2004). Human Resource Management: A Contemporary Approach: Financial Times Prentice Hall.

Echtner, C. M. (1995). Entrepreneurial training in developing countries. Annals of tourism research, 22(1), 119-134. 
Ehrlich, S. B., De Noble, A. F., Jung, D., \& Pearson, D. (2000). The impact of entrepreneurship training programs on an individual's entrepreneurial self-efficacy. Frontiers of entrepreneurship research.

Elmuti, D., Khoury, G., \& Omran, O. (2012). Does entrepreneurship education have a role in developing entrepreneurial skills and ventures' effectiveness. Journal of Entrepreneurship Education, 15(1), 83-98.

Farsi, J. Y., Arabiun, A., \& Moradi, M. (2012). The Impact of Opportunity Recognition Skills Training On Entrepreneurial Intention of Female Nursing Students. Scientific Board Members, 107.

Hui, H. (2012). Exploration of University Entrepreneurial Talent Training Mode. The Guide of Science \& Education, 11, 125.

Jusoh, R., Ziyae, B., Asimiran, S., \& Kadir, S. A. (2011). Entrepreneur training needs analysis: implications on the entrepreneurial skills needed for successful entrepreneurs. International Business \& Economics Research Journal (IBER), 10(1).

Ladzani, W. M., \& Van Vuuren, J. J. (2002). Entrepreneurship training for emerging SMEs in South Africa. Journal of Small Business Management, 40(2), 154-161.

Lashgarara, F., Roshani, N., \& Najafabadi, M. O. (2011). Influencing factors on entrepreneurial skills of rural women in Ilam City, Iran. African Journal of Business Management, 5(14), 5536-5540.

Luca, M. R., \& Cazan, A.-M. (2011). Involvement in entrepreneurial training and personality. Procedia-Social and Behavioral Sciences, $30,1251-1256$

Ogundele, O., Akingbade, W. A., \& Akinlabi, H. B. (2012). Entrepreneurship training and education as strategic tools for poverty alleviation in Nigeria. American International Journal of Contemporary Research, 2(1), 148-156.

Omar, N. A., Nazri, M. A., \& Wel, C. A. C. (2014). Entrepreneurial Training of Low-Income Women Micro Enterprises in the Service Sector in Malaysia: Understanding the Problems and Challenges. Journal of Social and Development Sciences, 5(4), 245-257.

Rodrigues, R. G., Dinis, A., do Paço, A., Ferreira, J., \& Raposo, M. (2012). The effect of an entrepreneurial training programme on entrepreneurial traits and intention of secondary students. Entrepreneurship-Born, made and educated, 77-92.

Roshan, M. R., Seifi, E., Abdollahi, B., Nokani, J., \& Banijamali, Z. (2015). The Relationship between the Teachers' Entrepreneurial Training (objectives, content, necessity, method and context of training) and the High school Students' Entrepreneurship Spirit. Quarterly Journal of New Thoughts on Education, 11(1), 151-179.

Rusinà, E., Dalla Pellegrina, L., Di Maio, G., \& Landoni, P. (2015). Money Management and Entrepreneurial Training in Microfinance: Impact on Beneficiaries and Institutions. University of Milan Bicocca Department of Economics, Management and Statistics Working Paper(296).

Sharma, S. (2014). Entrepreneurial training-to train them is to let them grow. International Journal of Research in IT and Management, $4(1), 61-72$

Teoh, W. M.-Y., \& Chong, S. (2008). Improving women entrepreneurs in small and medium enterprises in Malaysia: policy recommendations. Communications of the IBIMA, 2(5), 31-38.

Williams, D. A. (2015). Entrepreneurial Training and Business Discontinuation: A Cross Country Study. Journal of Business and Entrepreneurship, 26(3), 79.

Yamakawa, Y., \& Cardon, M. S. (2015). Causal ascriptions and perceived learning from entrepreneurial failure. Small Business Economics, 44(4), 797-820. 